Pediat. Res. 3: 597-604 (1969)

Cholesterol synthesis hyper-

cholesterolemia hyperproteinemia plasma infusion proteinuria

\title{
Hyperproteinemic Proteinuria Induced by Plasma Infusion
}

\author{
Peter N. MaLaine, Melvin I. Marks, Tadla Baliah, and Keith N. Drummond [39] \\ Renal Laboratory, McGill University-Montreal Ghildren's Hospital Research Institute, \\ Montreal, Quebec, Canada
}

\begin{abstract}
Extract
Five of seven children receiving plasma for correction of coagulation disorders developed transient proteinuria during 10 of 21 infusions. Frozen plasma with a mean protein and cholesterol concentration of $6.0 \mathrm{~g} / 100 \mathrm{ml}$ and $174 \mathrm{mg} / 100 \mathrm{ml}$, respectively, was used. In patients developing proteinuria, the mean volume of plasma infused per kilogram of body weight was $203.5 \mathrm{ml}$ as compared with $93.4 \mathrm{ml}$ in patients without proteinuria $(\mathrm{p}<0.001)$. The mean concentration of serum protein at onset of proteinuria was $9.6 \mathrm{~g} / 100 \mathrm{ml}$. The quantity of proteinuria ranged from 0.05 to $3.7 \mathrm{~g} / 12 \mathrm{~h}$ exceeding $0.5 \mathrm{~g} / 12 \mathrm{~h}$ in 7 of 10 study periods and $1.8 \mathrm{~g} / 12 \mathrm{~h}$ in four of five patients. Excretion of protein in the urine returned to normal values $2-7$ days following termination of the plasma infusion in three of five patients; in two patients who were discharged before proteinuria disappeared no evidence of proteinuria appeared upon subsequent follow-up. Differential protein clearance studies revealed highly selective proteinuria. A significant relation was observed between the serum cholesterol concentration and the corresponding serum protein level. With serum protein levels of $6.5-8.0 \mathrm{~g} / 100 \mathrm{ml}$ the mean cholesterol level was $209 \mathrm{mg} / 100 \mathrm{ml}$; with levels from 8.1 to $10.4 \mathrm{~g} / 100 \mathrm{ml}$ the mean cholesterol levels was $300 \mathrm{mg} / 100 \mathrm{ml}(\mathrm{p}<0.001)$. Prolonged plasma infusion may result in significant transient proteinuria.
\end{abstract}

\section{Speculation}

Elevation of serum protein concentration following plasma infusion renders the glomerular capillary basement membrane more permeable to proteins, particularly those proteins of low molecular weight, and proteinuria results. Changes in blood volume, glomerular filtration rate, or renal hemodynamics may be important in the development of proteinuria; however, hormonal, allergic or other metabolic responses to the nonautologous protein may also be operative. Induction of hyperproteinemia may lead to increased cholesterol synthesis or mobilization with resultant hypercholesterolemia; conversely, the hypercholesterolemia may be a reflection of an elevated lipoprotein concentration following plasma infusion. 


\section{Introduction}

Proteinuria has been observed $[11,26]$ in patients with hyperproteinemia resulting from multiple myeloma and Waldenstrom's macroglobulinemia whose renal function was otherwise normal. Proteinuria has also been produced in experimental animals following infusions of albumin and plasma $[9,29,30]$. We observed that children with normal renal function hospitalized for the correction of coagulation disorders developed proteinuria during infusions of plasma. This paper describes the frequency with which proteinuria developed during intravenous infusion of plasma, describes selectivity and relation to the plasma protein level, and discusses the possible mechanisms involved.

\section{Materials and Methods}

Seven children with coagulation disorders requiring infusions of plasma were studied on 21 separate admissions (table I). Frozen plasma [31] with a mean protein and mean cholesterol concentration of 6.0 $\mathrm{g} / 100 \mathrm{ml}$ and $174 \mathrm{mg} / 100 \mathrm{ml}$, respectively, was used. Renal disease was excluded by evidence that a physical examination, urinalysis, blood urea nitrogen, and serum creatinine were normal.

Prior to infusion of plasma, the serum and urine protein concentrations of the patients were determined. After infusion began, each urine was tested for proteinuria by a dipstick method [32]. If the concentration of protein in the urine was greater than $30 \mathrm{mg} /$ $100 \mathrm{ml}$, all subsequent urine was collected in $12-\mathrm{h}$ periods and the protein level was determined by a quantitative sulfosalicylic acid method [8, 17]. Proteinuria was defined as protein excreted in the urine in excess of $50 \mathrm{mg} / 12 \mathrm{~h}$. If this level was reached measurements were made every $24 \mathrm{~h}$ of total serum protein, cholesterol, and the selectivity of the urine protein. If proteinuria did not occur, the serum protein concentration was measured at the end of the plasma infusion. In eight of the study periods plasma had been infused before the usual base-line studies could be obtained. Urine was concentrated in dialysis tubing [33] 10-20 times against a sucrose medium for selectivity studies [20]. The volume of plasma infused during each $12-\mathrm{h}$ interval was recorded. Serum protein was measured by the biuret method [10]; cholesterol was measured by an autoanalyser technique [16].

Selectivity studies were performed with a modification of the methods of CAMERoN and White [6] and MAcLeAn and Robson [18]. Immunodiffusion plates [34] containing antibodies to human transferrin (mol wt 88,000), immunoglobulin G (IgG mol wt 150,000), and $\alpha_{2}$-macroglobulin (mol wt 840,000 ) were used to determine the urine-serum $(\mathrm{U} / \mathrm{S})$ ratios for each of these proteins. To calculate the relative clearances of these proteins the U/S ratios of both IgG and $\alpha_{2}$ macroglobulin were expressed as a percentage of the U/S ratio of transferrin $(100 \%)$ and plotted on a logarithmic scale against the respective molecular weights of these proteins. From the slope of the line obtained the angle theta $(\Theta)$ was measured. This angle reflects the degree of selectivity of the proteinuria; values in excess of $67^{\circ}$ indicate high selectivity; those less than $54^{\circ}$ represent poor selectivity [13].

\section{Results}

Proteinuria developed in 10 of the 21 study periods (table I). Two patients failed to develop proteinuria. The total volume of plasma infused ranged from 1,000 to $13,000 \mathrm{ml}$ and was administered over 1-16 days. In patients developing proteinuria, the mean volume of plasma infused per kilogram of body weight (fig. 1)

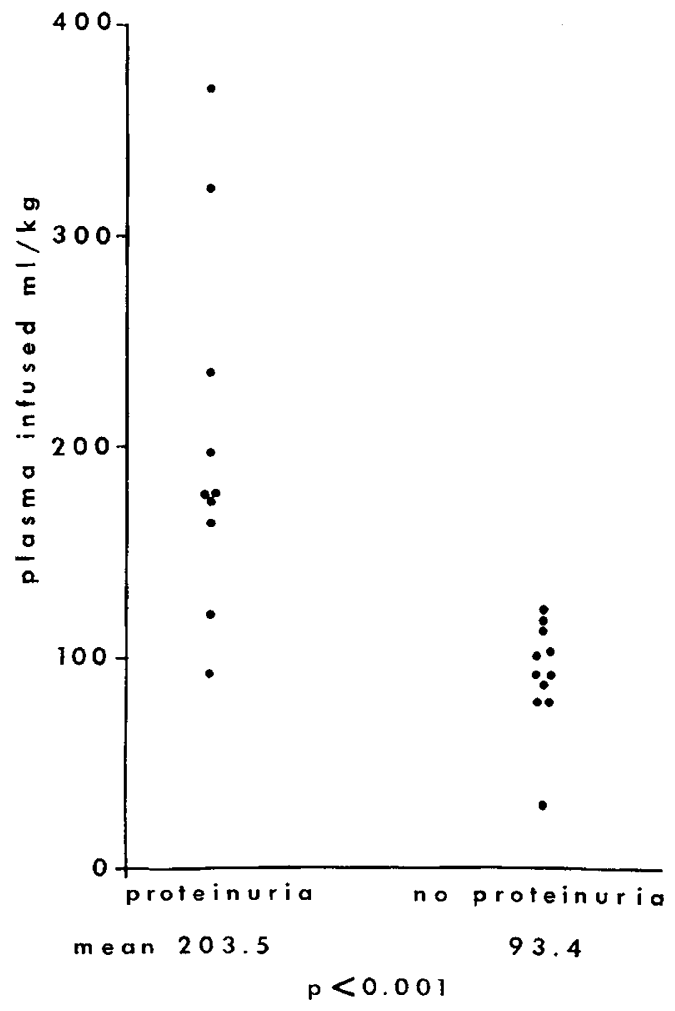

Fig. 1. The volume of plasma infused (ml/kg body wt) is compared in those study periods with proteinuria to those without proteinuria. The difference between these two groups is significant. 
Table I. Glinical and laboratory data

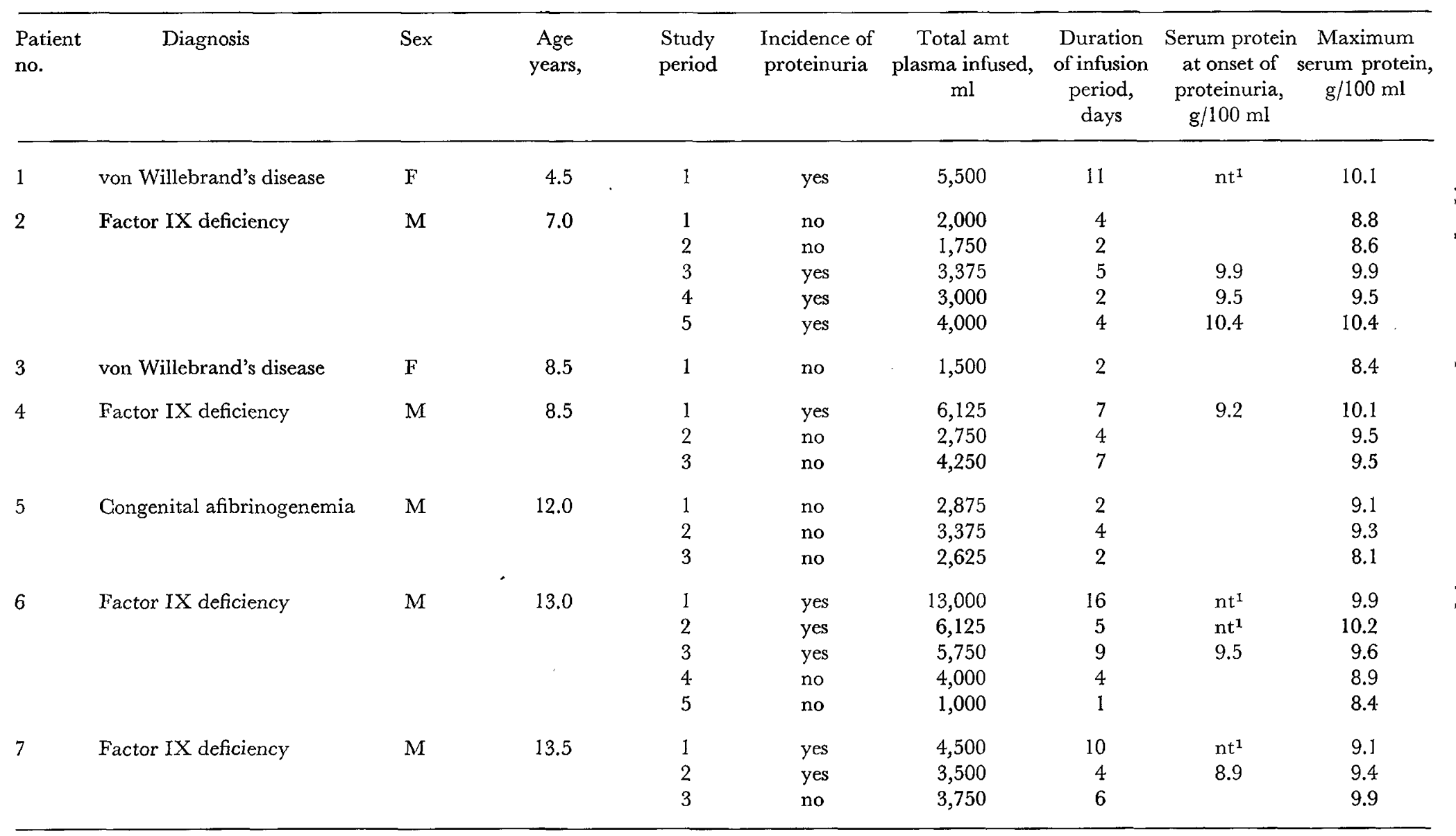

$\mathbf{1}=$ not tested 


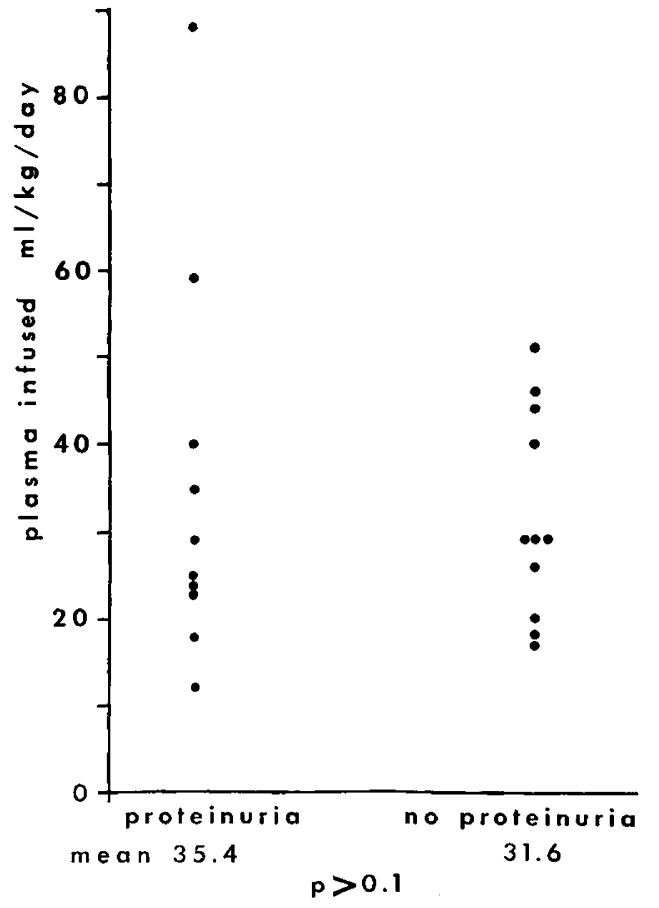

Fig. 2. The volume of plasma infused ( $\mathrm{ml} / \mathrm{kg}$ body $\mathrm{wt} /$ $24 \mathrm{~h}$ ) is compared in those study periods with proteinuria to those without proteinuria. The difference between these two groups is not significant.

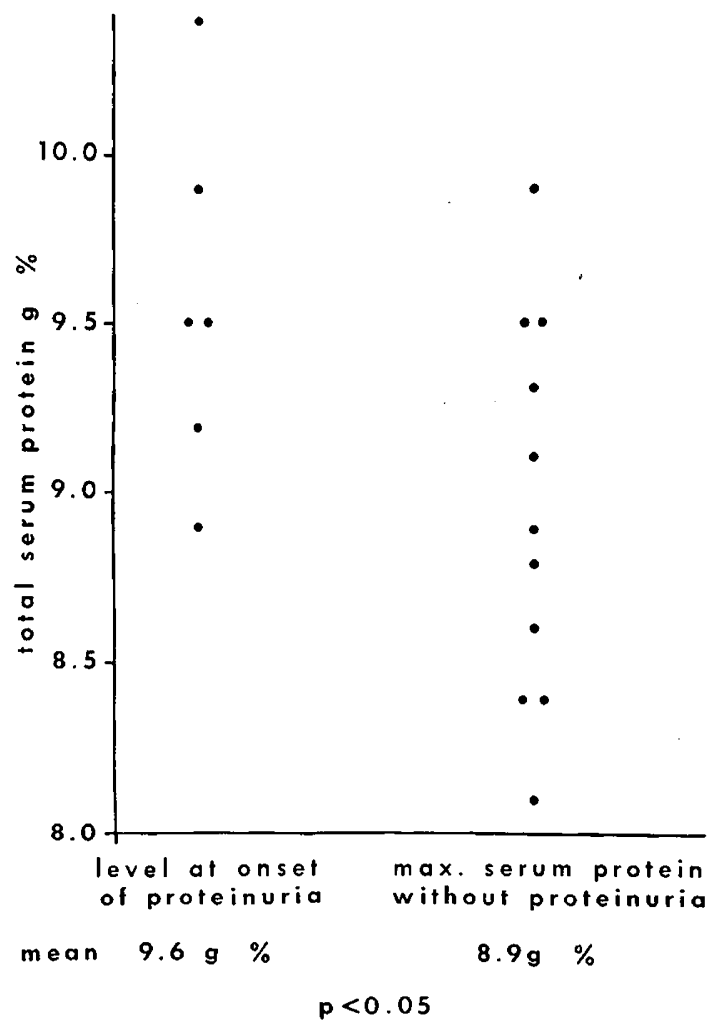

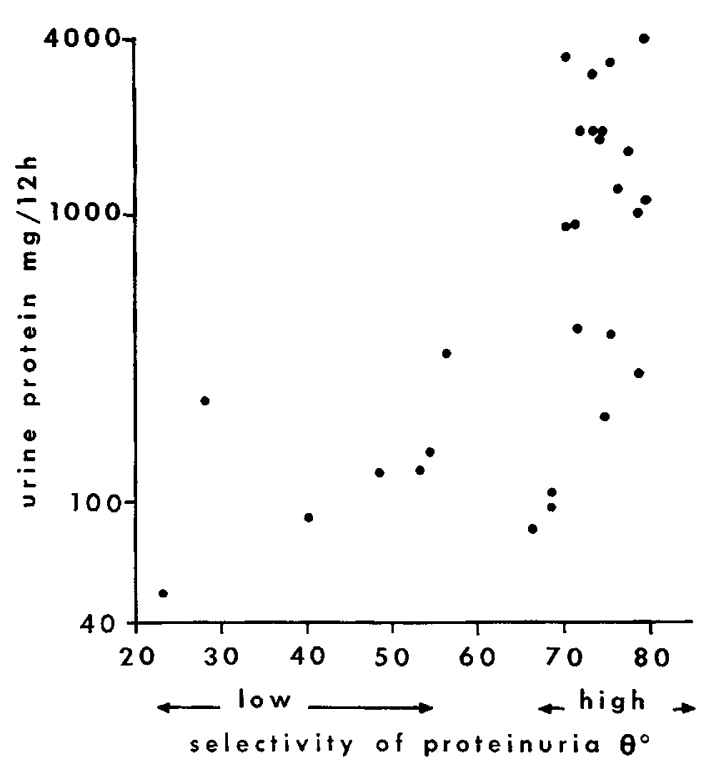

Fig. 4. The direct relation between the degree of selectivity of proteinuria and the quantity of protein excreted in the urine.

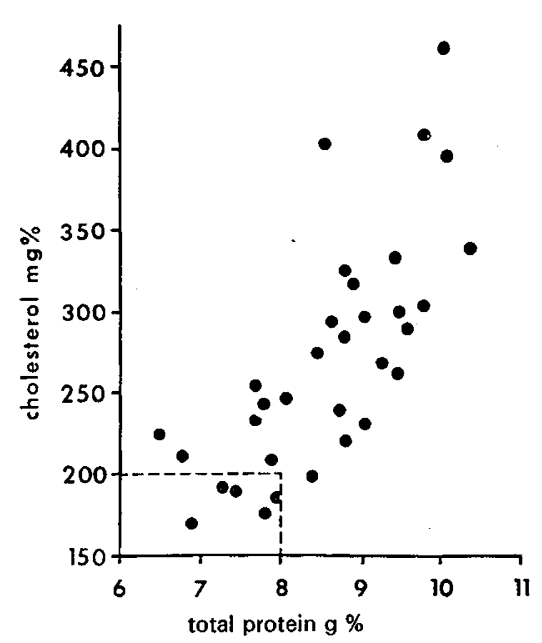

Fig.5. Total serum protein concentration is compared to corresponding serum cholesterol level. A direct relation was observed; the mean cholesterol concentration in the infused plasma was $174 \mathrm{mg} / 100 \mathrm{ml}$.

Fig. 3. Level of serum protein at the onset of proteinuria is compared to the maximum serum protein levels reached in those study periods without proteinuria. The difference between these two groups is significant. 
was $203.5 \mathrm{ml}(93.3-371.4 \mathrm{ml})$ as compared with 93.4 $\mathrm{ml}(28.6-123.2 \mathrm{ml})$ in patients without proteinuria $(\mathrm{p}<0.001)$. In patients with proteinuria, the mean volume of plasma infused per kilogram per day (fig. 2) was $35.4 \mathrm{ml}(12.0-88.2 \mathrm{ml})$ compared with $31.6 \mathrm{ml}$ $(16.7-51.5 \mathrm{ml})$ in those without proteinuria $(\mathrm{p}>0.1)$.

The concentration of serum protein at the onset of proteinuria was determined in 6 of the 10 periods (table I). Values ranged from 8.9 to $10.4 \mathrm{~g} / 100 \mathrm{ml}$ (mean $9.6 \mathrm{~g} / 100 \mathrm{ml}$ ) at this time as compared with the 11 periods in which proteinuria did not occur and in which the levels of serum protein ranged from 8.1 to $9.9 \mathrm{~g} / 100 \mathrm{ml}$ (mean $8.9 \mathrm{~g} / 100 \mathrm{ml}$ ) ( $\mathrm{p}<0.05$ ) (fig. 3). The level of serum protein in a given patient at the onset of proteinuria varied. In three of the study periods, in patients nos. 4 and 7, proteinuria failed to appear despite elevation of serum protein levels to a value above that at which proteinuria had previously developed. This suggests that no clearcut threshold for the onset of proteinuria exists. The quantity of proteinuria ranged from 0.05 to $3.7 \mathrm{~g} / 12 \mathrm{~h}$. Proteinuria exceeded $0.5 \mathrm{~g} / 12 \mathrm{~h}$ in 7 of 10 study periods and $1.8 \mathrm{~g} / 12 \mathrm{~h}$ in four of five patients. In three of the five patients, normal levels of protein excretion returned 2-7 days following termination of the plasma infusion. In the two patients who were discharged before proteinuria cleared, no evidence of protein in the urine was found upon subsequent follow-up.

Figure 4 shows a direct relation between the quantity of protein excreted in the urine and the degree of selectivity of proteinuria. Figure 5 illustrates the relation between the total serum protein concentration and the corresponding serum cholesterol levels. With serum protein levels of $6.5-8.0 \mathrm{~g} / 100 \mathrm{ml}$ the mean cholesterol level was $209 \mathrm{mg} / 100 \mathrm{ml}$; with protein levels of $8.1-10.4 \mathrm{~g} / 100 \mathrm{ml}$ the corresponding mean cholesterol level was $300 \mathrm{mg} / 100 \mathrm{ml}(\mathrm{p}<0.001)$.

\section{Discussion}

In children with normal renal function but with coagulation disorders, transient proteinuria was induced by infusions of plasma. This reaction had been observed with experimental animals following infusions of a few hours or of several days duration $[15,22,29,30]$. Light and electron-microscopic studies of renal parenchyma had demonstrated swelling, vacuolization and foot process fusion of glomerular epithelial cells $[9,30]$, but these changes were considered secondary to the proteinuria and reversible. In dogs, proteinuria developed when the serum protein was raised to levels between 9.6 and $10.4 \mathrm{~g} / 100 \mathrm{ml}$ [29]. In our patients, the levels ranged from 8.9 to $10.4 \mathrm{~g} / 100 \mathrm{ml}$ at the onset of proteinuria.
Proteinuria of different etiology may be characterized by differential protein clearances. Postural proteinuria and excretion of protein by the normal kidney are poorly selective $[24,25]$; most patients with a minimal lesion nephrotic syndrome have highly selective proteinuria $[6,28]$. Proteinuria was highly selective in the majority of patients in our study periods, which may be interpreted as a relative increase in glomerular basement membrane permeability to proteins of low molecular weight.

The mechanism of proteinuria following infusion of plasma is not known. BuIss and co-workers studied the effect of autologous and nonautologous plasma infusion in animals and man and described a number of hypersensitivity reactions in the nonautologous group [1-4]. These reactions were characterized by histamine release and increased capillary permeability with extravascation of plasma into the interstitial tissues. Increased capillary permeability has also been attributed to a vasoactive substance in the infused plasma [5]. Such factors may play a role in altering permeability of glomerular capillary basement membranes as well, and thus, may be involved in the development of the proteinuria we observed.

Studies in humans and animals receiving albumin or plasma infusions $[7,21,22]$ have revealed increases in plasma volume, but findings in relation to changes in glomerular filtration rate or renal plasma flow have not been consistent. These variables were not measured but might be of value in elucidating the mechanism of proteinuria in these patients.

A relation was observed between the serum cholesterol level and the degree of hyperproteinemia. Many explanations for hyperlipemia in proteinuric states have been proposed and include the role of hypoalbuminemia [23], increased lipid and low density $\beta$-lipoprotein synthesis [19], and mobilization of hepatic cholesterol into the intravascular compartment [27]. The patients were not hypoalbuminemic; no attempt was made to study lipid or lipoprotein metabolism. Both hyper- and hypocholesterolemia have been reported in analogous experimental work in rats in whom hyperproteinemic proteinuria had been induced by parenteral protein administration [12, 14].

\section{References and Notes}

1. BLISs, J.Q. and Johns, D. G.: Responses to autologous and nonautologous plasma transfusions in dogs. Rev. Canad. Biol. 16: 469 (1957).

2. Bliss, J.Q. and Stewart, P.B.: The selectivity response of skin to autologous and non-autologous 
plasma in non-sensitized subjects. Canad.med. Ass.J. 76: 847 (1957).

3. Bliss, J.Q.; Stewart, P.B. and Fuller, J.L.: The selective cutaneous response to autologous and non-autologous plasma in dogs: observations on the effects of inbreeding and of immaturity. Brit.J.exp. Path. 39: 30 (1958).

4. Bliss, J.Q. and WAlker, J. D.: Histamine release by homologous plasma in the dog. Canad.J. Biochem. 37: 371 (1959).

5. Bohr, D.F. and Johansson, B.: Contraction of vascular smooth muscle in response to plasma. Circulat. Res. 19: 593 (1966).

6. Cameron, J.S. and White, R.H.R.: Selectivity of proteinuria in children with the nephrotic syndrome. Lancet $i$ : 463 (1965).

7. Cargill, W.H.: Effect of the intravenous administration of human serum albumin on renal function. Proc. Soc. exp. Biol., N.Y. 68: 189 (1948).

8. Crpriani, A. and Brophy, D.: A method for determining cerebrospinal fluid protein by the photoelectric colorimeter. J.Lab.clin. Med. 28: 1269 (1943).

9. Fisher, E.R. and Hellstrom, H. R.: Mechanism of proteinuria. Lab. Invest. 11: 617 (1962).

10. Gornall, A. G.; Bardawill, C.J. and David, M.: Determination of serum proteins by means of biuret reaction. J. biol. Chem. 177: 751 (1949).

11. Harrison, J.F.; Blainey, J.D.; Hardwick, J.; Rowe, D.S. and Soothill, J.F.: Proteinuria in multiple myeloma. Clin. Sci. 31: 95 (1966).

12. Hirano, T.; Dorfman, H.D. and Hollander, V.P.: Studies on hyperproteinemia and proteinuria in rats bearing a mammosomatotropic tumor. Endocrinology 80: 305 (1967).

13. Joachim, G.R.; Cameron, J.S.; Schwartz, M. and BECKER, E. L. : Selectivity of protein excretion in patients with the nephrotic syndrome. J.clin. Invest. 43: 2332 (1964).

14. Karl, I.E.; Garcia, P.; White, W.L.; Recant, L. and Kissatre, J.M.: Proteinuria induced by albumin injection: Effect of kidney and liver enzymes in the rat. Lab. Invest. 13: 1600 (1964).

15. Lannigan, R. and MaQueen, E. G.: The effect on the renal glomerular epithelial cells of proteinuria induced by infusions of human serum albumin in rabbits and rats. Brit. J. exp. Path. 43: 549 (1962).

16. Levine, J.B. and ZAK, B.: Automated determination of serum total cholesterol. Clin. chim. Acta 10: 381 (1964).

17. Looney, J.M. and WALSh, I.A.: The determination of spinal fluid protein with the photoelectric colorimeter. J. biol. Chem. 127: 117 (1939).

18. MAcLean, P.R. and Robson, J. S. : A simple meth- od for determining selectivity of proteinuria. Lancet $i: 539$ (1967).

19. MARsh, J.B. and Drabkin, D.L.: Experimental reconstruction of metabolic pattern of lipid nephrosis: Key role of hepatic protein synthesis in hyperlipemia. Metabolism 9: 946 (1960).

20. McFarLane, H.: A simple method for concentrating urine for protein electrophoresis. Glin. chim. Acta 9: 376 (1964).

21. Petersdorf, R.G. and Welt, L.G. : The effect of an infusion of hyperoncotic albumin on the excretion of water and solutes. J. clin. Invest. 32: 283 (1953).

22. Rosenfeld, S.; Kraus, R. and MaCullen, A.: Effect of renin, ischemia and plasma protein loading on the isolated perfused kidney. Amer.J. Physiol. 209: 835 (1965).

23. Rosenman, R.H.; Friedman, M. and Byers, S. O.: The causal role of plasma albumin deficiency in experimental nephrotic hyperlipemia and hypercholesterolemia. J. clin. Invest. 35: 522 (1956).

24. Rowe, D.S. and Soothill, J.F.: Serum proteins in normal urine. Clin. Sci. 21: 75 (1961).

25. Rowe, D.S. and Soothil, J.F.: The proteins of postural and exercise proteinuria. Clin. Sci. 21: 87 (1961).

26. Snapper, I.; Turner, L. B. and Moskovitz, H.L. : Multiple myeloma; p.43 (Grune and Stratton, New York 1953).

27. Sodhi, H.S. and Kalant, N.: Hyperlipemia of antiserum nephrosis. II. Turnover of plasma cholesterol. Metabolism 12: 414 (1963).

28. SoothILL, J.F.: Studies on proteinuria with special reference to immunochemically determined differential protein clearances. Guy's Hosp. Rep. 111: 355 (1962).

29. Terry, R.: Proteinuria related to hyperproteinemia in dogs following plasma given parenterally. J.exp. Med. 87: 561 (1948).

30. Vernier, R.L.; Papermaster, B.W.; Olness, K.; Binet, E. and Good, R.A.: Morphologic studies of the mechanism of proteinuria. (Abstract) Amer. J. Dis. Child. 100: 476 (1960).

31. Supplied by the Canadian Red Cross.

32. Albustix, Ames Company of Canada, Ltd., Toronto, Canada.

33. Dialyzer tubing, seamless cellulose, Fisher Scientific Company, Ltd., Montreal, Quebec, Canada.

34. Immunoplate, Hyland Division, Travenol Laboratories, Inc., Los Angeles, Calif.

35. Presented in part at the Annual Meeting of the American Society for Pediatric Research, Atlantic City, N.J., May 3, 1969.

36. We are grateful to Dr. R.L. Denron and Dr. R. GouRdEAU for permission to study the patients under their care. 
37. Dr. K.N.Drummond, Associate Professor, Department of Pediatrics, McGill University and Director, Renal Laboratory, Montreal Children's Hospital; Dr. M.I. MARks, present address: Department of Pediatric Infectious Disease, University of Colorado Medical Center, Denver Colorado; Dr. T. BALIAH, present address: Hospital for Sick Children, Toronto, Canada.
38. Aided by Medical Research Council of Canada Term Grant no. MT-1579 and the Kidney Disease Foundation of Canada. Dr. P.N.McLaine is a Fellow of the Medical Research Council of Canada. 39. Requests for reprints should be addressed to $\mathrm{K}_{\mathrm{EITH}}$ N. Drummond, M.D., Director, Renal Laboratory, Montreal Children's Hospital, 2300 Tupper Street, Montreal 25, Quebec (Canada). 